Journal of Animal and Veterinary Advances 9 (8): 1216-1222, 2010

ISSN: $1680-5593$

(C) Medwell Journals, 2010

\title{
Effects of Dietary Protein on Nitrogen Metabolism and Protein Requirements for Maintenance of Growing Thai Swamp Buffalo (Bubalus bubalis) Calves
}

\author{
${ }^{1} \mathrm{P}$. Tatsapong, ${ }^{1} \mathrm{P}$. Peangkoum, ${ }^{2} \mathrm{O}$. Pimpa and ${ }^{3} \mathrm{M}$.D. Hare \\ ${ }^{1}$ Institute of Agricultural Technology, Suranaree University of Technology, \\ Nakhon Ratchasima, 30000, Thailand \\ ${ }^{2}$ Faculty of Technology and Management, Price of Songkla University, \\ Surat Thani Campus, Surat Thani, 84100, Thailand \\ ${ }^{3}$ Faculty of Agriculture, Ubon Ratchathani University, Ubon Ratchathani, 34190, Thailand
}

\begin{abstract}
The experiment was conducted to investigate the effect of dietary crude protein on nitrogen utilization, nutrient digestibility and protein requirement for maintenance of swamp buffalo calves. Four growing swamp male buffaloes with 12-18 months old (average initial weight $209 \pm 17 \mathrm{~kg}$ ) were used. The calves were assigned to use a $4 \times 4$ Latin square design to receive four diets. In terms of treatment, Crude Protein (CP) levels in the diets were $5,7,9$ and $11 \%$ of Dry Matter (DM) and all diets were isocaloric ( $20 \%$ above maintenance of $\mathrm{ME})$. CP intake and CP digestibility of calves clearly increased $(\mathrm{p}<0.05)$ with increasing $\mathrm{CP}$ content in diet. However, increasing the levels of dietary protein did not significantly alter ( $\mathrm{p}>0.05) \mathrm{DM}$ intake, digestibility of $\mathrm{DM}$, organic matter, neutral detergent fiber and acid detergent fiber, body weight change and ruminal $\mathrm{pH}$ in calves. As the level of $\mathrm{CP}$ in diet increased, blood urea nitrogen, ruminal ammonia $\mathrm{N}$, total volatile fatty acid, urinary $\mathrm{N}, \mathrm{N}$ retention and $\mathrm{N}$ balance were observed to increase linearly $(\mathrm{p}<0.05)$. While $\mathrm{N}$ fecal was not significantly different $(\mathrm{p}>0.05)$, when dietary protein levels increased. The relationship between $N$ Balance $(\mathrm{NB})$ and $\mathrm{N}$ intake $\left(\mathrm{NI}, \mathrm{g} \mathrm{kg}^{-1} \mathrm{~W}^{0.75}\right)$ in swamp buffalo calves was $\mathrm{NB}=0.883 \mathrm{NI}-0.653\left(\mathrm{R}^{2}=0.855\right)$. Present findings suggested that nitrogen requirements for maintenance of growing Thai swamp buffalo calves were $0.74 \mathrm{~g} \mathrm{~N}$ or $4.63 \mathrm{~g} \mathrm{CP} \mathrm{kg}^{-1} \mathrm{BW}^{0.75}$.
\end{abstract}

Key words: Swamp buffalo, buffalo calves, Bubalus bubalis, protein requirement, $\mathrm{N}$ balance, protein for maintenance

\section{INTRODUCTION}

In order to meet their production potential, ruminants have to consume the required amounts of nutrients from the diet. The nutrition of buffalo male calves is important as it plays a role in the onset of puberty in calves raised for breeding and it influences the quantity and quality of the meat produced by the calves. Subsequently, dietary protein supply is one of the factors that influence the productivity of animals. Feeding high levels of protein may be effective in promoting rapid live weight gains, especially growing buffalo (Basra et al., 2003b). Currently, there is an insufficient information concerning the effect of protein on nutrient digestibility and nitrogen metabolism in Thai swamp buffalo. Chantiratikul et al. (2009) and Chumpawadee et al. (2009) found that CP digestibility and $\mathrm{N}$ retention of Thai indigenous heifers increased with increasing dietary CP levels. Study of nutritional requirements of buffalo is necessary because of the NRC $(1996,2001)$ standard suggested for beef or dairy cattle. Although, the nutrition requirement of buffalo has been determined by Kearl (1982), it can not be accurately applied for swamp buffalo. Basra et al. (2003b) reported that lower protein requirements for Nii ravi buffalo male calves than cattle calves, while the $\mathrm{CP}$ requirements for growth may be the same as suggested for Holstein Friesian calves (Basra et al., 2003a).

On the other hand, the digestible $\mathrm{CP}$ requirement for maintenance of buffalo was $2.54 \mathrm{~g} \mathrm{~kg}^{-1} \mathrm{BW}^{0.75}$ day (Kearl, 1982), the Metabolisable Protein (MP) requirement for maintenance was 4.03-6.3 $\mathrm{g} \mathrm{kg}^{-1} \mathrm{BW}^{0.75}$ day for growing Nii ravi buffalo at 125-400 kg (Paul and Patil, 2007). It has been indicated that the optimum fattening performance of 15 months old Nii ravi buffalo male calves may be obtained by providing $10.22 \% \mathrm{CP}$ (Mahmoudzadeh et al., 2007) and $12 \%$ CP for 11-12 months old (Tipu et al., 2009). The nutrition needs of the buffalo probably differ from type of breeds found

Corresponding Author: P. Peangkoum, Institute of Agricultural Technology, Suranaree University of Technology, Nakhon Ratchasima, 30000, Thailand 
in temperate countries because of difference in genetic make-up, mature body size, growth rate, composition of body tissue, quality of feed and climatic conditions (Kearl, 1982).

Therefore, research on the requirement of nutrients for Thai swamp buffalo does not exist and adequate information on the nutritional requirements of growing buffalo male calves is lacking. Hence, this experiment was conducted to determine the effect of increasing dietary protein levels on nitrogen utilization, nitrogen balance and protein requirements for maintenance of growing Thai swamp buffalo calves.

\section{MATERIALS AND METHODS}

Animals, diet and experimental design: Four growing male swamp buffalo (Bubalus bubalis) calves (12-18 months of age and $209 \pm 17 \mathrm{~kg}$ average body weight) were randomly assigned into a $4 \times 4$ Latin square design to receive four levels of crude protein $(5,7,9$ and $11 \% \mathrm{CP})$ in the diets.

The energy content of diets were formulated to contain a metabolisable energy intake of $20 \%$ above Maintenance $(\mathrm{M})$ as determined by a review literature of the $\mathrm{M}=1.62 \mathrm{Mcal} \mathrm{kg}^{-1} \mathrm{DM}$ (Kearl, 1982). All animals were fed rice straw as roughage, cassava pulp and soybean meal as an energy and protein source according to the respective treatments. In order to increase the palatability of the diet, molasses was added. All concentrate diets were mixed daily and fed twice daily at 08:00 $\mathrm{h}$ in the morning and 16:00 $\mathrm{h}$ in the evening. During the experiment period, the animals were kept in well ventilated shed and concrete floor with individual feeding and watering arrangement. The animals were given 14 days for adaptation to diets at the start of each period, followed by 7 days collection period and 7 days for rest period. For the rest period, all animals were fed ad libitum of rice straw and $1.5 \% \mathrm{BW}$ of concentrate $(12 \% \mathrm{CP})$. Animals were fasted to measure N-retention on the last 4 days of the experiment.

Data collection and sampling procedures: Feed offered and orts were weighed and recorded daily and sampled every 3 days and the composites prior to chemical composition analysis. The feces and urine were collected daily from day 3-7 of collection period. The daily feces was weighed and mixed well and a $10 \%$ sub sample was taken and stored frozen. At the end of each collection period the daily fecal samples were bulked for each animal. Ten percent of each mixed well-bulked sample was taken for calculation of digestibility of DM, OM, CP, NDF and ADF. Daily collection of urine were acidified with $25 \%$ $\mathrm{H}_{2} \mathrm{SO}_{4}$ to kept the final $\mathrm{pH}$ of the urine below 3 and then weighed and it was sampled the same fecal samples for determination of urine nitrogen. Feed, orts and fecal sample were dried at $60^{\circ} \mathrm{C}$ and analyzed for proximate principles (AOAC, 1990) and fibre analysis was determined by methods supported by Van Soest et al. (1991).

At the end of each collection period, the rumen fluid was taken $(200 \mathrm{~mL})$ from the middle part of the rumen by a stomach tube connected with a vacuum pump at 0 and $4 \mathrm{~h}$ after morning feed. Ruminal $\mathrm{pH}$ was measured immediately after sampling using a potable $\mathrm{pH}$ meter and then, samples were filtered through nylon bag. Five milliliter of $1 \mathrm{M} \mathrm{H}_{2} \mathrm{SO}_{4}$ was added to $50 \mathrm{~mL}$ of rumen fluidto terminate fermentation. The mixture was centrifuged at $3,500 \mathrm{rpm}$ for $15 \mathrm{~min}$ and the clear supernatant was stored in plastic bottle at $-20^{\circ} \mathrm{C}$ until analyzed for ruminal ammonia nitrogen $\left(\mathrm{NH}_{3}-\mathrm{N}\right)$ (Bremner and Keeney, 1965) and Volatile Fatty Acids (VFA) concentrations were determined by GC (Hewlett-Packard GC system HP6890 A; Hewlett-Packard Avondale, PA).

Blood samples were collected at the same time rumen fluid sampling for determine Blood Urea Nitrogen (BUN) concentration. The blood was drawn from the jugular vein into tube $(10 \mathrm{~mL}$ for sample) and centrifuged at 3,500 rpm for 15-20 min and serum was separated and stored frozen at $-20^{\circ} \mathrm{C}$ until analyzed for BUN (Crocker, 1967).

Statistical analysis: Nitrogen requirement for maintenance were estimated by determining the average Nitrogen Balance (NB) of buffaloes fed different levels of protein. In order to estimate dietary $\mathrm{N}$ requirement for maintenance, the $\mathrm{NB}$ and $\mathrm{N}$ intake were inserted into regression equation: Nitrogen balance $=\mathrm{N}$ balance index $\mathrm{x}(\mathrm{N}$ intake $)-\mathrm{N}$ loss at zero $\mathrm{N}$ intake, where $\mathrm{N}$ requirement $(\mathrm{Nm})$ for maintenance equals to $\mathrm{N}$ intake, when $\mathrm{N}$ balance is zero.

The data were analyzed as a $4 \times 4$ Latin Square Design using the GLM procedure of SAS (1996). To treatment means comparisons were conducted by Duncan's New Multiple Rang Test using Proc GLM (SAS, 1996).

\section{RESULTS AND DISCUSSION}

Chemical composition of dietary treatments: Chemical composition of dietary treatment and ingredients feed used in the experiment are shown in Table 1. All diet treatments had similar chemical composition but difference in crude protein levels. Crude protein concentrations in dietary treatments were 5.1, 7.09, 9.12 and $11.16 \%$ of DM and Metabolisable Energy (ME) concentrations in all diets were $2.14 \mathrm{Mcal} \mathrm{kg}^{-1} \mathrm{DM}$. However, CP and ME remained constant among dietary treatments. 
Table 1: Ingredients and chemical composition of dietary treatments Dietary crude protein levels (\%)

\begin{tabular}{|c|c|c|c|c|}
\hline \multirow[b]{2}{*}{ Ingredients } & \\
\hline & 5 & 7 & 9 & 11 \\
\hline Rice straw & 66.22 & 65.48 & 65.39 & 65.78 \\
\hline Cassava pulp & 26.04 & 22.50 & 18.18 & 13.38 \\
\hline Soybean meal & 4.26 & 8.56 & 12.94 & 17.32 \\
\hline Molasses & 3.37 & 3.36 & 3.38 & 3.40 \\
\hline Premix $^{1}$ & 0.11 & 0.11 & 0.11 & 0.11 \\
\hline Total & 100.00 & 100.00 & 100.00 & 100.00 \\
\hline \multicolumn{5}{|c|}{ Chemical composition (DM \%) $)^{2}$} \\
\hline Dry Matter (DM, kg) & 3.90 & 3.91 & 3.88 & 3.85 \\
\hline Organic Matter (OM) & 87.30 & 87.69 & 87.55 & 87.36 \\
\hline Crude Protein (CP) & 5.10 & 7.09 & 9.12 & 11.16 \\
\hline Neutral Detergent Fibre (NDF) & 56.78 & 56.16 & 55.91 & 55.92 \\
\hline Acids Detergent Fibre (ADF) & 40.58 & 39.87 & 39.42 & 39.11 \\
\hline $\mathrm{ME}\left(\mathrm{Mcal} \mathrm{kg}^{-1} \mathrm{DM}\right)$ & 2.13 & 2.14 & 2.14 & 2.14 \\
\hline
\end{tabular}

${ }^{1}$ The premix provided per kilogram of DM: $10,000 \mathrm{IU}$ vitamin; 2,000 IU vitamin $\mathrm{D}_{3} ; 20 \mathrm{IU}$ vitamin $\mathrm{E} ; 10 \mathrm{mg} \mathrm{Cu} ; 80 \mathrm{mg} \mathrm{Mn} ; 40 \mathrm{mg} \mathrm{Zn;} 50 \mathrm{mg} \mathrm{Fe}$; $0.8 \mathrm{mg} \mathrm{I} ; 0.3 \mathrm{mg} \mathrm{Se} ; 0.3 \mathrm{mg} \mathrm{Co} ;{ }^{2}$ Calculated

Live-weight change, intake and digestibility: Average body weight and body weight change of buffalo calves did not significantly different among treatment (Table 2). However, the animals lost weight, when they were fed low dietary protein during the experiment. In this way, they received $20 \%$ above maintenance of $\mathrm{ME}$. The unbalance in nutrient intake to compare with minimum requirement of buffalo calves for growth (Kearl, 1982) may explain the weight loss.

Total DM intake of the calves, in terms of $\mathrm{kg}$ per day $\left(\mathrm{kg} \mathrm{day}^{-1}\right)$ and $\mathrm{g}$ per kilograms metabolic weight ( $\mathrm{g} \mathrm{kg}^{-1} \mathrm{~W}^{0.75}$ ) were not affected by increasing dietary protein content (Table 2). Similarly, Basra et al. (2003a), Yuangklang (2009) and Chantiratikul et al. (2009) demonstrated that daily DM intake for calves fed different $\mathrm{CP}$ diet did not significantly. Average of DM intake in calves was $3.86 \mathrm{~kg}$ calf ${ }^{-1}$ day or $68 \mathrm{~g} \mathrm{~kg}^{-1} \mathrm{~W}{ }^{0.75}$ day. Therefore, the daily CP intake in calves, in terms of $\mathrm{g}_{\text {day }}{ }^{-1}$ and $\left(\mathrm{g} \mathrm{kg}^{-1} \mathrm{~W}^{0.75}\right)$ were increased $(\mathrm{p}<0.05)$ with increasing CP levels in diet. The CP intake $\left(\mathrm{g} \mathrm{kg}^{-1} \mathrm{~W}^{0.75}\right)$ was $3.47,4.85,6.15$ and 7.55 with ratios $5,7,9$ and $11 \%$ $\mathrm{CP}$, respectively, where as digestible CP intake was $0.97,2.26,3.40$ and $5.02\left(\mathrm{~g} \mathrm{~kg}^{-1} \mathrm{~W}^{0.75}\right)$, respectively (Table 2).

This result are in agreement with previous studies in growing Nii ravi buffalo (Basra et al., 2003a, b), in growing indigenous heifers (Chantiratikul et al., 2009; Chumpawadee et al., 2009), in Korean black goats (Hwangbo et al., 2009) and in yearling indigenous Thai native cattle (Paengkoum and Tatsapong, 2009) that observed CP or nitrogen intake was sharply affected by dietary protein concentration.

Digestibility of CP of calves shows in Table 2, it was higher $>50 \%$ in comparison to the 5 and $11 \% \mathrm{CP}$ in diet. CP digestibility was significantly higher in increasing CP content in diets (Paengkoum and Tatsapong, 2009;
Chantiratikul et al., 2009; Chumpawadee et al., 2009). Dietary protein levels did not considerably alter $(\mathrm{p}>0.05)$ $\mathrm{DM}, \mathrm{OM}, \mathrm{NDF}, \mathrm{ADF}$ and TDN digestibility in animals (Table 2). This result similarly, the previous research in Thai-indigenous heifers (Chantiratikul et al., 2009) that observed DM, NDF and ADF digestibilities were not affected by dietary protein content. However, Chumpawadee et al. (2009) reported that increasing dietary $\mathrm{CP}$ indicated in significant increase in NDF and $\mathrm{ADF}$ digestibilities but DM and $\mathrm{OM}$ digestibilities did not different in yearling heifers. In additionally, Paengkoum and Tatsapong (2009) found that DM and $\mathrm{OM}$ digestibilities increased but NDF and $\mathrm{ADF}$ digestibilities did not differed following to the levels of dietary protein content. The different suggested that results regarding effects of dietary protein on nutrient digestibility were possibly due to multiple factors such as animal condition, breed, sex, dietary CP levels and balance of dietary protein and available carbohydrate (Mcdonald et al., 1995). Javaid et al. (2008) demonstrated that increasing the levels of dietary Ruminally Degradable Protein (RDP) resulted in a linear decreased in crude protein and neutral detergent fiber digestibility but increase in dry matter digestibility in Nii ravi buffalo bulls.

\section{Blood Urea Nitrogen (BUN) and ruminal fermentation:} As shown in Table $3, \mathrm{BUN}$, concentration of $\mathrm{NH}_{3}-\mathrm{N}$, Volatile Fatty Acid (VFA) and $\mathrm{pH}$ in rumen fluid were presented to monitor the ruminal fermentation pattern and valves measured at 0 and $4 \mathrm{~h}$ post feeding. Ruminal $\mathrm{pH}$ was similar among diet and the values were quite stable at 7.0-7.1. This finding was similar previous reviewed (Chantiratikul et al., 2009; Peangkoum and Tatsapong, 2009; Chumpawadee et al., 2009) who explained that the ruminal $\mathrm{pH}$ was not affected by increasing dietary protein. Nisa et al. (2006) and Khan et al. (2006) reported that ruminal $\mathrm{pH}$ values at $12 \mathrm{~h}$ after feeding of buffaloes fed $12 \% \mathrm{CP}$ in the diet were ranged 7.0-7.2. However, ruminal $\mathrm{pHs}$ of all calves were in the normal ranged (6.7-7.0) which has been found as optimal for microbial digestion of protein (Wanapat, 1999). Normally, rate and extent of carbohydrates digestion are influenced ruminal $\mathrm{pH}$ which in the large amount of soluble carbohydrates may reduce the ruminal $\mathrm{pH}$. Based on this study the animals were received 20\% above maintenance of energy. Moreover, increasing dietary $\mathrm{RDP}$ due to reduced ruminal $\mathrm{pH}$ and increased ruminal $\mathrm{NH}_{3}-\mathrm{N}$ (Javaid et al., 2008). In spite of the ammonia nitrogen in the rumen linearly, increased with increasing protein content (Table 3) but it did not alter ruminal $\mathrm{pH}$. It was probably, the buffering capacity can maintained the ruminal $\mathrm{pH}$. 
J. Anim.Vet. Adv., 9 (8): 1216-1222, 2010

Table 2: Effect of dietary protein on nutrients intake, digestibility and body weight change of swamp buffalo calves

\begin{tabular}{|c|c|c|c|c|c|c|c|c|}
\hline \multirow[b]{2}{*}{ Items } & \multicolumn{4}{|c|}{ Dietary crude protein levels (\%) } & \multirow[b]{2}{*}{ SEM } & \multicolumn{3}{|c|}{ Contrast } \\
\hline & 5 & 7 & 9 & 11 & & $\mathrm{~L}$ & $Q$ & $\mathrm{C}$ \\
\hline BW change $\left(\mathrm{kg} \mathrm{day}^{-1}\right)$ & 0.04 & -0.01 & -0.13 & 0.23 & 0.12 & NS & NS & NS \\
\hline DMI $\left(\mathrm{kg} \mathrm{day}^{-1}\right)$ & 3.84 & 3.89 & 3.85 & 3.84 & 0.04 & NS & NS & NS \\
\hline DMI $\left(\mathrm{g} \mathrm{kg}^{-1} \mathrm{~W}^{0.75}\right)$ & 67.85 & 68.34 & 67.65 & 67.54 & 0.31 & NS & NS & NS \\
\hline CPI $\left(\mathrm{g} \mathrm{kg}^{-1} \mathrm{DM}\right)$ & $51.1^{\mathrm{d}}$ & $71.01^{c}$ & $90.94^{b}$ & $111.78^{a}$ & 0.20 & 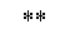 & NS & NS \\
\hline CPI $\left(\mathrm{g} \mathrm{kg}^{-1} \mathrm{~W}^{0.75}\right)$ & $3.47^{\mathrm{d}}$ & $4.85^{c}$ & $6.15^{b}$ & $7.55^{\mathrm{a}}$ & 0.04 & *** & NS & NS \\
\hline DCPI $\left(\mathrm{g} \mathrm{kg}^{-1} \mathrm{~W}^{0.75}\right)$ & $0.97^{\mathrm{d}}$ & $2.26^{\mathrm{c}}$ & $3.40^{b}$ & $5.02^{\mathrm{a}}$ & 0.13 & $* *$ & NS & NS \\
\hline \multicolumn{9}{|c|}{ Apparent digestibilities (\%) } \\
\hline $\mathrm{DM}$ & 55.88 & 55.30 & 53.25 & 57.06 & 2.15 & NS & NS & NS \\
\hline OM & 64.33 & 63.89 & 62.46 & 65.67 & 1.77 & NS & NS & NS \\
\hline $\mathrm{CP}$ & $27.82^{\mathrm{d}}$ & $46.49^{c}$ & $55.11^{\mathrm{b}}$ & $66.50^{\mathrm{a}}$ & 1.95 & $* *$ & NS & NS \\
\hline $\mathrm{NDF}$ & 47.51 & 46.03 & 43.68 & 49.30 & 2.48 & NS & NS & NS \\
\hline $\mathrm{ADF}$ & 42.89 & 40.89 & 37.24 & 41.88 & 2.90 & NS & NS & NS \\
\hline TDN & 93.84 & 94.10 & 93.32 & 93.60 & 0.74 & NS & NS & NS \\
\hline
\end{tabular}

${ }^{a-d}$ Values on the same row under each main effect with different superscript differ significantly ( $<<0.05$ ); BW $=$ Body Weight; DMI = Dry Matter Intake; $\mathrm{CPI}=$ Crude Protein Intake; $\mathrm{DM}=$ Dry Matter; $\mathrm{OM}=$ Organic Matter; $\mathrm{CP}=$ Crude Protein; $\mathrm{ADF}=$ Acid Detergent Fiber; NDF $=$ Neutral Detergent Fiber; TDN = Total Digestibility Nutrient; SEM = Standard Error of Means; NS = Not Significantly different ( $p>0.05$ ); L, Q, C = Linear, Quadratic and Cubic effects of difference crude protein levels; **Significantly different $(\mathrm{p}<0.01)$

Table 3: Effects of dietary protein on ruminal $\mathrm{pH}$, ruminal ammonia nitrogen $\left(\mathrm{NH}_{3}-\mathrm{N}, \mathrm{mg} \%\right.$ ), blood urea nitrogen (BUN, mg \%) and Volatile Fatty Acid (VFA) of swamp buffalo calves

\begin{tabular}{|c|c|c|c|c|c|c|c|c|}
\hline \multirow[b]{2}{*}{ Items } & \multicolumn{4}{|c|}{ Dietary crude protein levels (\%) } & \multirow[b]{2}{*}{ SEM } & \multicolumn{3}{|c|}{ Contrast } \\
\hline & 5 & 7 & 9 & 11 & & $\mathrm{~L}$ & Q & $\mathrm{C}$ \\
\hline \multicolumn{9}{|c|}{ h-post-feeding } \\
\hline \multicolumn{9}{|c|}{ Ruminal $\mathrm{pH}$} \\
\hline 0 & $7.03^{b}$ & $7.33^{\mathrm{a}}$ & $7.18^{\mathrm{ab}}$ & $7.28^{\mathrm{a}}$ & 0.05 & $*$ & NS & * \\
\hline 4 & 7.05 & 6.88 & 7.12 & 7.10 & 0.10 & NS & NS & NS \\
\hline Mean & 7.04 & 7.10 & 7.15 & 7.18 & 0.05 & NS & NS & NS \\
\hline \multicolumn{9}{|c|}{ Ruminal NH3-N (mg \%) } \\
\hline 0 & $12.20^{\circ}$ & $16.25^{b}$ & $19.36^{\mathrm{a}}$ & $19.52^{\mathrm{a}}$ & 0.33 & **** & 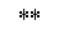 & NS \\
\hline 4 & $11.77^{\circ}$ & $14.56^{\text {bc }}$ & $17.03^{\mathrm{ab}}$ & $18.42^{\mathrm{a}}$ & 1.07 & **:* & NS & NS \\
\hline Mean & $11.98^{c}$ & $15.41^{\mathrm{b}}$ & $18.20^{\mathrm{a}}$ & $18.97^{\mathrm{ab}}$ & 0.62 & ****: & NS & NS \\
\hline \multicolumn{9}{|c|}{ Blood urea nitrogen (mg \%) } \\
\hline 0 & $12.63^{\mathrm{c}}$ & $18.56^{\text {bc }}$ & $23.81^{\mathrm{ab}}$ & $27.31^{\mathrm{a}}$ & 2.42 & 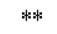 & NS & NS \\
\hline 4 & $12.39^{\circ}$ & $21.13^{b}$ & $22.67^{\mathrm{ab}}$ & $29.03^{\mathrm{a}}$ & 2.16 & $* * *$ & NS & NS \\
\hline Mean & $12.51^{\mathrm{b}}$ & $19.85^{\mathrm{ab}}$ & $23.24^{\mathrm{a}}$ & $28.17^{\mathrm{a}}$ & 2.25 & **** & NS & NS \\
\hline \multicolumn{9}{|c|}{ Total volatile fatty acids $\left(\mathrm{mM} \mathrm{L}^{-1}\right)$} \\
\hline 0 & 66.98 & 65.13 & 66.15 & 68.82 & 1.52 & NS & NS & NS \\
\hline 4 & $64.12^{b}$ & $67.11^{b}$ & $70.50^{\mathrm{ab}}$ & $75.95^{\mathrm{a}}$ & 2.02 & ***: & NS & NS \\
\hline Mean & $65.55^{b}$ & $66.12^{b}$ & $68.32^{b}$ & $72.39^{\mathrm{a}}$ & 0.84 & $* * * *$ & NS & NS \\
\hline \multicolumn{9}{|c|}{ Acetate $(\mathrm{mol} / 100 \mathrm{~mol})$} \\
\hline 0 & $69.28^{b}$ & $71.23^{\mathrm{ab}}$ & $71.08^{\mathrm{ab}}$ & $73.30^{\mathrm{a}}$ & 0.89 & $*$ & NS & NS \\
\hline 4 & 70.74 & 69.99 & 67.69 & 68.46 & 0.93 & NS & NS & NS \\
\hline Mean & 70.01 & 69.61 & 69.39 & 70.88 & 0.77 & NS & NS & NS \\
\hline \multicolumn{9}{|c|}{ Propionate $(\mathrm{mol} / 100 \mathrm{~mol})$} \\
\hline 0 & 21.87 & 20.57 & 21.89 & 20.23 & 0.80 & NS & NS & NS \\
\hline 4 & 21.43 & 22.34 & 22.52 & 22.49 & 0.68 & NS & NS & NS \\
\hline Mean & 21.65 & 21.45 & 22.21 & 21.36 & 0.66 & NS & NS & NS \\
\hline \multicolumn{9}{|c|}{ Butyrate $(\mathrm{mol} / 100 \mathrm{~mol})$} \\
\hline 0 & $8.85^{\mathrm{a}}$ & $8.20^{\mathrm{ab}}$ & $7.04^{\mathrm{bc}}$ & $6.47^{\mathrm{c}}$ & 0.48 & *k*k & NS & NS \\
\hline 4 & $7.83^{b}$ & $9.68^{a}$ & $9.79^{\mathrm{a}}$ & $9.05^{\mathrm{ab}}$ & 0.44 & NS & $*$ & NS \\
\hline Mean & 8.34 & 8.94 & 8.42 & 7.76 & 0.40 & NS & NS & NS \\
\hline $\mathrm{C}_{2}: \mathrm{C}_{3}$ & 3.24 & 3.26 & 3.13 & 3.33 & 0.13 & NS & NS & NS \\
\hline
\end{tabular}

a-dValues on the same row under each main effect with different superscript differ significantly ( $p<0.05$ ); $S E M=$ Standard Error of Means; NS = Not Significantly different ( $p>0.05) ; \mathrm{L}, \mathrm{Q}, \mathrm{C}=$ Linear, Quadratic and Cubic effects of difference crude protein levels; "Significantly different ( $<<0.05)$; **:Significantly different $(\mathrm{p}<0.01)$

Ruminal $\mathrm{NH}_{3}-\mathrm{N}$ concentration were also different $(\mathrm{p}<0.05)$ at each hour of sampling. It has been demonstrated that increased protein intake increased ammonia nitrogen concentration in rumen. In the study, values of ruminal $\mathrm{NH}_{3}-\mathrm{N}$ ranged from $12-19 \mathrm{mg} \mathrm{dL}^{-1}$ and its normal range was considered optimum in swamp buffaloes (Wanapat and Pimpa, 1999). Furthermore, the increases in rumen $\mathrm{NH}_{3}-\mathrm{N}$ levels also indicated in increasing levels of BUN (Javaid et al., 2008; Wanapat and Pimpa, 1999) and the values were linearly increased as levels of dietary protein increased in the diets (Table 3). Average BUN were 12.5, 19.8, 23.2 
and $26.5 \% \mathrm{mg}$ in calves fed diets $5,7,9$ and $11 \% \mathrm{CP}$, respectively. The result are in agreement with previous research in Thai-indigenous yearling heifers (Chumpawadee et al., 2009), Thai-indigenous steers (Paengkoum and Tatsapong, 2009), growing finishing Brahman cattle (Yuangklang, 2009) and Thai native and Brahman crossbred (Paengkoum and Yanee, 2009) found that increased BUN was associated with the elevation of $\mathrm{NH}_{3}-\mathrm{N}$ in the rumen. Therefore, the ruminal $\mathrm{NH}_{3}-\mathrm{N}$ increased, when protein intake increased may have been related directly to protein degradation is more rapid than synthesis, high dietary RDP (Javaid et al., 2008; Sultan et al., 2009) or imbalance of fermentable energy, so ammonia will accumulate in rumen fluid and the optimum concentration will be exceeded. Thus, ammonia is absorbed into the blood and also excreted via urine in to high levels of urine nitrogen (Javaid et al., 2008; Yuangklang, 2009; Chantiratikul et al., 2009).

Total Volatile Fatty Acids (TVFAs) concentrations in rumen fluid were significantly different among treatment $(p<0.05)$, which ranged from $65-72 \mathrm{mM} \mathrm{L}^{-1}$. The values increased linearly $(\mathrm{p}<0.01)$ as a consequence of additional $\mathrm{CP}$ in the diet. This results similarly reported by Paengkoum and Yanee (2009), who study in yearling Brahman $x$ Thai native beef cattle. In addition, acetic acid was increased linearly with increasing protein levels in diet that observed before feeding, while butyric acid was decreased, when protein increased. However, propionic acid and proportion of acetic and propionic were not affected by dietary protein concentrations. The results are in agreement with previous observed in Thai-Indigenous heifers (Chumpawadee et al., 2009). Generally, rate and extent of volatile fatty acids production were influenced by carbohydrate fraction and degradability of carbohydrate (Mcdonald et al., 1995).

N metabolism: The $\mathrm{N}$ intake, $\mathrm{N}$ balance, $\mathrm{N}$ excretion in urine and $\mathrm{N}$ retention were increased significantly $(\mathrm{p}<0.05)$ when dietary protein levels increased (Table 4). Similarly results were suggested in male Thai native beef cattle (Paengkoum and Tatsapong, 2009; Sereethai et al., 2009), in growing finishing Brahman cattle (Yuangklang, 2009) and in Thai-indigenous heifers (Chantiratikul et al., 2009). The present study found that nitrogen balance ranged $0.03-0.3 \mathrm{~g} \mathrm{~N} \mathrm{~kg}^{-1} \mathrm{~W}^{0.75}$ and $\mathrm{N}$ retained ranged $0.54-0.86 \mathrm{~g}$ $\mathrm{N} \mathrm{kg}^{-1} \mathrm{~W}^{0.75}$, when the calves consumed dietary protein from $5-11 \%$ CP of DM. There was linear increase $(\mathrm{p}<0.05)$ in urinary $\mathrm{N}\left(6.93,11.70,22.93\right.$ and $28.52 \mathrm{~g}$ day $\left.^{-1}\right)$ by increasing $(5,7,9$ and $11 \% \mathrm{CP})$ protein content in the diets (Table 4). However, there was no significant difference in fecal $\mathrm{N}$ among diets, it can be explained that endogenous loss from digestive tract may be not different in each animal (Kearl, 1982). It has been reported that $\mathrm{N}$ excretion through urine was increased due to $\mathrm{CP}$ diet and $\mathrm{N}$ intake (Pimpa et al., 2009; Mehra et al., 2006) and also directly to relate RDP ratio in dietary protein (Sultan et al., 2009), high RDP ratio in dietary protein were increased urine $\mathrm{N}$ but decreased $\mathrm{N}$ balance (Javaid et al., 2008). Normally, when protein degradation is more rapid than synthesis, so ammonia will accumulate in rumen liquor and is absorbed into the blood carried to the liver and converted to urea and it was excreted via to urine $\mathrm{N}$ (Mcdonald et al., 1995). The values of $\mathrm{N}$ balance were regressed linearly for the determination of dietary nitrogen requirement for maintenance (Fig. 1). The regression equation between $\mathrm{N}$ balance and $\mathrm{N}$ intake of calves is $\mathrm{N}$ balance $\left(\mathrm{g} \mathrm{N} \mathrm{kg}^{-1}\right.$ $\left.\mathrm{W}^{0.75}\right)=0.883 \mathrm{~N}$ intake $-0.653\left(\mathrm{R}^{2}=0.855\right)$. This equation can be used to estimate $\mathrm{N}$ requirement for maintenance, the $\mathrm{N}$ intake at which $\mathrm{N}$ balance equal to zero were $0.74 \mathrm{~g}$ $\mathrm{N} \mathrm{kg}^{-1} \mathrm{~W}^{0.75}$ day. Consequently, nitrogen requirements for maintenance for growing swamp buffalo calves are $0.74 \mathrm{~g} \mathrm{~N} \mathrm{~kg}^{-1} \mathrm{~W}^{0.75}$ or equivalent to $4.63 \mathrm{~g} \mathrm{CP} \mathrm{kg}^{-1} \mathrm{~W}^{0.75}$ day or as approximately $6 \%$ of dietary crude protein. These finding were in an agreement with previous reported in yearling Thai native cattle $\left(4.36 \mathrm{~g} \mathrm{CP} \mathrm{kg}^{-1}\right.$ $\mathrm{W}^{0.75}$ day) by Sereethai et al. (2009), in Thai southern

Table 4: Effect of dietary protein on $\mathrm{N}$ metabolites of swamp buffalo calves

\begin{tabular}{|c|c|c|c|c|c|c|c|c|}
\hline \multirow[b]{2}{*}{ Items } & \multicolumn{4}{|c|}{ Dietary srude protein levels (\%) } & \multirow[b]{2}{*}{ SEM } & \multicolumn{3}{|c|}{ Contrast } \\
\hline & 5 & 7 & 9 & 11 & & $\mathrm{~L}$ & $Q$ & $\mathrm{C}$ \\
\hline $\mathrm{N}$ intake $\left(\mathrm{g}\right.$ day $^{-1}$ ) & $31.40^{d}$ & $44.16^{c}$ & $56.04^{b}$ & $68.71^{\mathrm{a}}$ & 0.75 & $* *$ & NS & NS \\
\hline $\mathrm{N}$ intake $\left(\mathrm{g} \mathrm{kg}^{-1} \mathrm{~W}^{0.75}\right)$ & $0.55^{\mathrm{d}}$ & $0.78^{c}$ & $0.98^{b}$ & $1.21^{\mathrm{a}}$ & 0.006 & $* *$ & NS & NS \\
\hline Urine $\mathrm{N}\left(\mathrm{g}_{\text {day }}{ }^{-1}\right)$ & $6.93^{b}$ & $11.70^{b}$ & $22.93^{\mathrm{a}}$ & $28.52^{\mathrm{a}}$ & 1.76 & $* *$ & NS & NS \\
\hline Urine $\mathrm{N}$ (\% of $\mathrm{N}$ intake) & $22.00^{b}$ & $26.56^{b}$ & $40.83^{\mathrm{a}}$ & $41.21^{\mathrm{a}}$ & 2.85 & $* * *$ & NS & NS \\
\hline Fecal N $\left(\mathrm{g} \mathrm{day}^{-1}\right)$ & 22.71 & 23.58 & 25.09 & 23.12 & 0.94 & NS & NS & NS \\
\hline Fecal $N(\%$ of $N$ intake $)$ & $72.18^{\mathrm{a}}$ & $53.51^{\mathrm{b}}$ & $44.89^{c}$ & $33.50^{\mathrm{d}}$ & 1.95 & *** & NS & NS \\
\hline $\mathrm{N}$ balance $\left(\mathrm{g} \mathrm{day}^{-1}\right)$ & $1.76^{\mathrm{c}}$ & $8.87^{b}$ & $8.02^{b}$ & $17.06^{\mathrm{a}}$ & 1.36 & $* *$ & NS & * \\
\hline $\mathrm{N}$ balance $\left(\mathrm{g} \mathrm{kg}^{-1} \mathrm{~W}^{0.75}\right)$ & $0.03^{\mathrm{d}}$ & $0.16^{b}$ & $0.14^{b}$ & $0.31^{\mathrm{a}}$ & 0.03 & $* *$ & NS & * \\
\hline $\mathrm{N}$ endogenous $\left(\mathrm{g} \mathrm{kg}^{-1} \mathrm{~W}^{0.75}\right)$ & 0.56 & 0.55 & 0.56 & 0.56 & 0.004 & NS & NS & NS \\
\hline $\mathrm{N}$ retention $\left(\mathrm{g}\right.$ day $\left.^{-1}\right)$ & $30.62^{c}$ & $40.28^{b}$ & $39.43^{b}$ & $48.47^{\mathrm{a}}$ & 1.57 & **** & NS & * \\
\hline $\mathrm{N}$ retention $\left(\mathrm{g} \mathrm{kg}^{-1} \mathrm{~W}^{0.75}\right)$ & $0.54^{c}$ & $0.71^{b}$ & $0.70^{b}$ & $0.86^{\mathrm{a}}$ & 0.03 & $* * *$ & NS & $*$ \\
\hline
\end{tabular}




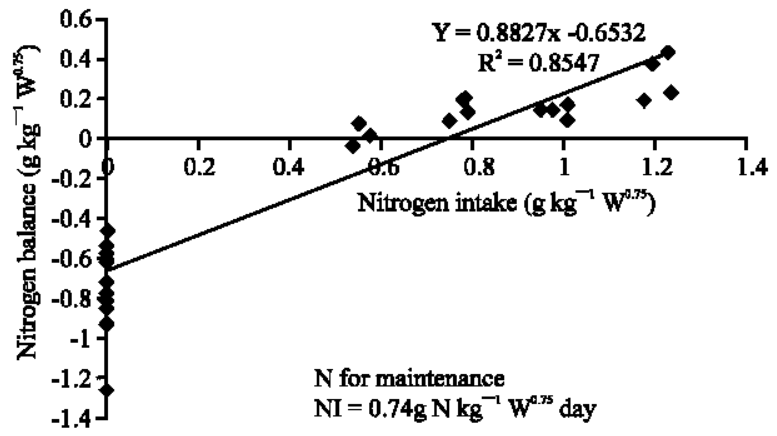

Fig. 1: Relationship between $\mathrm{N}$ balance and $\mathrm{N}$ intake $\left(\mathrm{g} \mathrm{kg}^{-1} \mathrm{~W}^{0.75}\right.$ ) in swamp buffalo calves

native cattle $\left(0.17-0.78 \mathrm{~g} \mathrm{~N} \mathrm{~kg}^{-1} \mathrm{~W}^{0.75} \mathrm{day}^{-1}\right)$ by Pimpa et al. (2009), in Thai-indigenous heifers (176 g CP day $^{-1}$ or $4.5 \mathrm{~g} \mathrm{CP} \mathrm{kg}^{-1} \mathrm{~W}^{0.75}$ day) by Chantiratikul et al. (2009). Based on the result indicated that protein requirement for maintenance of calves are approximately $14 \%$ lower than (Kearl, 1982) $5.4 \mathrm{~g} \mathrm{CP} \mathrm{kg}^{-1} \mathrm{~W}^{0.75}$ and $12 \%$ $<5.3 \mathrm{~g} \mathrm{CP} \mathrm{kg}^{-1} \mathrm{~W}^{0.75}$ (NRC, 1996).

This results are in an agreement with Basra et al. (2003b), who indicated that in Nii ravi buffalo male calves (12-15 months of age) and Tauqir et al. (2009a), who reported that in Nii ravi buffalo calves (6-7 months of age) found that protein requirements of Nii ravi buffalo calves are lower than dairy cattle calves was recommended by NRC (2001). However, Paul and Patil (2007) demonstrated that the maintenance requirement of $\mathrm{CP}$ of Nii ravi buffalo heifers were $5.89-9.38 \mathrm{~g} \mathrm{CP} \mathrm{kg}^{-1} \mathrm{~W}^{0.75}$ for $125-400$ body weight ranges. Whereas protein requirement for growth of Nii ravi buffalo male calves ( $9-12$ months of age) is same as NRC described for cattle (Basra et al., 2003a). In contrast, Tauqir et al. (2009b) suggested that CP requirements of Nii ravi buffalo calves (12-15 months of age) is higher than recommended by NRC (2001) for cattle.

\section{CONCLUSION}

From this study, it can be concluded that increasing dietary protein significantly increased $(\mathrm{p}<0.05) \mathrm{CP}$ digestibility and modified $N$ utilization $(p<0.05)$ in growing Thai swamp buffalo calves. Protein requirements for maintenance for growing swamp buffalo calves are $4.63 \mathrm{~g} \mathrm{CP} \mathrm{kg}^{-1} \mathrm{~W}^{0.75}$ day and the result was lower than Kearl and NRC recommendation.

\section{ACKNOWLEDGEMENTS}

The researchers would like to cordially thank the Office of the Higher Education Commission, Thailand for supporting by grant fund under the program strategic
Scholarships for Frontier Research Network for this financial support of research.

Institute of Agricultural Technology and Suranaree University of Technology farm provided laboratory facilities and experimental place of research, respectively.

\section{REFERENCES}

AOAC, 1990. Official Methods of Analysis of Association of Analytical Chemistry. 15th Edn., AOAC., Arlington, Virginia, pp: 1298.

Basra, M.J., M. Nisa, M.A. Khan, M. Riaz, N.A. Tuqeer and M.N. Saeed, 2003a. Nili-Ravi buffalo II. Energy and protein requirements of 9-12 months old calves. Int. J. Agric. Biol., 5: $380-381$.

Basra, M.J., M. Nisa, M.A. Khan, M. Riaz, N.A. Tuqeer and M.N. Saeed, 2003b. Nili-Ravi buffalo III. Energy and protein requirements of 12-15 months old calves. Int. J. Agric. Biol., 5: 382-383.

Bremner, J.M. and D.R. Keeney, 1965. Steam distillation methods of determination of ammonia, nitrate and nitrite Anal. Chem. Acta, 32: 485-495.

Chantiratikul, A., P. Chantiratikul, S. Chumpawadee and W. Kanchanamayoon, 2009. Effect of dietary protein on nutrient digestibility and nitrogen metabolism in thai-indigenous heifers. J. Anim. Vet. Adv., 8: 297-300.

Chumpawadee, S., A. Chantiratikul, V. Rattanphun, C. Prasert and K. Koobkaew, 2009. Effect of dietary crude protein levels on nutrient digestibility, ruminal fermentation and growth rate in ThaiIndigenous yearling heifers. J. Anim. Vet. Adv., 8: 1131-1136.

Crocker, C.L., 1967. Rapid determination of urea nitrogen in serum or plasma without deproteinzation. Am. J. Med. Technol., 33: 361-365.

Hwangbo, S., S.H. Choi, S.W. Kim, D.S. Son, H.S. Park, S.H. Lee and I.K. Hwan-Jo, 2009. Effects of crude protein levels in total mixed rations on growth performance and meat quality in growing Korean black goats. Asian-Aust. J. Anim. Sci., 22: $1133-1139$.

Javaid, A., M. Hr-un-Nisa, M. Sarwar and M.A. Shahzad, 2008. Runinal characteristics, blood $\mathrm{pH}$, blood urea nitrogen and nitrogen balance in Nili ravi buffalo (Bubalus bubalis) bulls fed diets containing various levels of ruminally degradable protein. Asian-Aust. J. Anim. Sci., 21: $51-58$. 
Kearl, L.C., 1982. Nutrient Requirements of Ruminants in Developing Countries. 1st Edn. International Feedstuffs Institute, Utah State University, Logan, Utah, USA.

Khan, M.A., M. Sarwar, M. Nisa, S.A. Khan and M.S. Bhatti et al., 2006. Feeding value of urea treated wheat straw ensiled with or without acidified molassed in Nili ravi buffaloes. Asian-Aust. J. Anim. Sci., 19: 645-650.

Mahmoudzadeh, M., H. Fazaeil, I. Kordnejad and H.R. Mirzael, 2007. Response of male bufflo calves to different levels of energy and protein in finishing diets. Pak. J. Biol. Sci., 10: 1398-1405.

Mcdonald, P., R.A. Edwards, J.E.D. Greenhalgh and C.A. Morgan, 1995. Animal Nutrition. 5th Edn., Perntice Hall, United States, pp: 693.

Mehra, U.R., M.Y. Khan, M. Lal, Q.Z. Hasan and A. Das et al., 2006. Effect of sources of supplementary protein on intake, digestion and efficiency of energy utilization in buffaloes fed wheat straw based diets. Asian-Aust. J. Anim. Sci., 19: 638-644.

NRC, 1996. Nutrients Requirements of Beef Cattle. 7th Edn., National Academy Press, Washington, pp: 242.

NRC, 2001. Nutrient Requirements of Dairy Cattle. 7th Edn., National Academies Press, Washington, DC., USA., ISBN: 0309069971, pp: 381.

Nisa, M.U., M.A. Khan, M. Sarwar, W.S. Lee and H.J. Lee et al., 2006. Infuence of corn steep liquor on feeding value of urea treated wheat straw in buffaloes fed at restrited diets. Asian-Aust. J. Anim. Sci., 19: 1610-1616.

Paengkoum, P. and P. Tatsapong, 2009. Effect of Different Levels of Protein on Feed Intake, Digestibility and Growth Rate of Thai Native Beef Cattle Fed Pangola Grass as Roughages. In: Establishment of a Feeding Standard of Beef Cattle and a Feed Database for the Indochiness Peninsula, Oshio, S., M. Otsuka and K. Sommart (Eds.). JRCAS., Tsukuba, Ibaraki, Japan, pp: 76-78.

Paengkoum, P. and R. Yanee, 2009. Protein Requirement of Yearling Brahman $\mathrm{x}$ Thai Native Beef Cattle. In: Establishment of a Feeding Standard of Beef Cattle and a Feed Database for the Indochiness Peninsula, Oshio, S., M. Otsuka and K. Sommart (Eds.). JRRAS., Tsukuba, Ibaraki, Japan, pp: 73-75.

Paul, S.S. and N.V. Patil, 2007. Energy and protein requirements of growing Nili ravi buffalo heifers in tropical environment. J. Sci. Food Agric., 87: 2286-2293.
Pimpa, O., S. Ruengsuwan and B. Pimpa, 2009. Protein Requirements for Maintenance and Growing of Thai Southern Native Cattle: Practical Feeding Trail on Farm of South-Thailand. In: Establishment of a Feeding Standard of Beef Cattle and a Feed Database for the Indochiness Peninsula, Oshio, S., M. Otsuka and K. Sommart (Eds.). JRCAS., Tsukuba, Ibaraki, Japan, pp: 86-89.

SAS, 1996. SAS User's Guide: Statistics. 14th Edn., SAS Institute, Cary, NC.

Sereethai, S., K. Thummasaeng and W. Suriyapat, 2009. Protein Requirement for Maintenance of Yearling Thai Native Cattle. In: Establishment of a Feeding Standard of Beef Cattle and a Feed Database for the Indochiness Peninsula, Oshio, S., M. Otsuka and K. Sommart (Eds.). JRCAS., Tsukuba, Tbaraki, Japan, pp: 83-85.

Sultan, J.I., A. Javaid, M. Nadeem, M.Z. Akhtar and M.I. Mustafa, 2009. Effect of varying ruminally degradable to ruminally undegrable protein ratio on nutrient intake, digestibility and $\mathrm{N}$ metabolism in $\mathrm{Nili}$ Ravi buffalo calves (Bubalus bubalis). Livest. Sci., 122: 130-133.

Tauqir, N.A., M.A. Tipu, M. Fayyaz and M. Aziz, 2009a. Nutrients requirement of growing Nili-ravi buffalo calves at 12-15 months of age. Buffalo Research Institute, Pattoki, District Kasur.

Tauqir, N.A., M.A. Tipu, M. Fayyaz and M. Aziz, $2009 \mathrm{~b}$. Performance of buffalo calves reared on different plans of nutrition with varying levels of protein and energy. Buffalo Research Institute, Pattoki, District Kasur.

Tipu, M.A., R.H. Mirza, F. Ahmad, N.A. Tauqir and M. Aziz, 2009. Effect of varying levels of dietary protein on the performance of growing Nili-ravi buffalo male calves. Buffalo Research Institute, Pattoki, District Kasur.

Van Soest, P.J., J.B. Robertson and B.A. Lewis, 1991. Methods for dietary fiber, neutral detergent fiber and nonstarch polysaccharides in relation to animal nutrition. J. Dairy Sci., 74: 3583-3597.

Wanapat, M. and O. Pimpa, 1999. Effect of ruminal $\mathrm{NH}_{3} \mathrm{~N}$ levels on ruminant fermentation, purine derivatives, digestibility and rice straw intake in swamp buffaloes. Asian-Aust. J. Anim. Sci., 12: 904-907.

Wanapat, M., 1999. Feeding of Ruminants in the Tropics Based on Local Feed Resources. Khon Kaen Publishing Company Ltd., Thailand, pp: 236.

Yuangklang, C., 2009. Protein Requirement for Growing Finishing Brahman Cattle. In: Establishment of a Feeding Standard of Beef Cattle and a Feed Database for the Indochiness Peninsula, Oshio, S., M. Otsuka and K. Sommart (Eds.). JRCAS., Tsukuba, Ibaraki, Japan, pp: 79-82. 